\title{
CRIMINAL SANCTIONS FOR GROUP LIBEL: FEASIBILITY AND CONSTITUTIONALITY
}

\author{
JAMES A. SCOTT*
}

[“. . . callousness to the rights of individuals and minorities leads to barbarism and the destruction of the essential values of civilized life."1]

When Joseph Beauharnais, president of the "White Circle League of America," recently published and had publicly exhibited in Chicago matter portraying Negroes as depraved, criminal, unchaste, and lacking in virtue, he was perhaps unaware of the existence of an Mlinois group libel statute $^{2}$ under which he might be-and was-convicted. Probably more to his dismay, however, was the overruling by the Illinois Supreme Court of his claim of immunity under the free speech and press shields of the United States and Illinois Constitutions. ${ }^{3}$

The Illinois Court rejected as having no conclusive bearing upon the question of the constitutionality of the Illinois statute the cases of Thornhill $v$. Alabama, Terminiello $v$. City of Chicago, ${ }^{5}$ and Near v. Minnesota. ${ }^{6}$ In an opinion by Fulton, J., the Court proceeded:

"The Supreme Court of the United States and this Court have held that the freedom of speech and of the press, which is secured by the Constitution, does not confer an absolute right to speak or publish, without responsibility, whatever one may choose, or an unrestricted and unbridled license that gives immunity for every possible use of language and prevents the punishment of those who abuse this language."?

* 3rd Year Law Student Duke University; A.B. Duke University 1947.

1 People v. Barber, 289 N.Y. 378, 386, 46 N.E. $2 d$ 329, 332 (1943).

2 ILL. Rev. Stat., Chap. 38, Par. 471 (1949). Quoted infra p. 230. This statute has been unchanged in form since original passage in 1917.

3 People v. Beauharnais, _ _ Il1. —, 97 N.E. 2d 343 (1951).

310 U.S. 105 (1940).

- 337 U.S. 1 (1949).

- 283 U.S. 697 (1931).

? People v. Beauharnais, supra note 3, cfting Gitlow v. New York, 
After repeating the "clear and present danger" test, the Court stated that a mere reading of the publication in question showed it libelous in that it contained " 'fighting words' liable to cause violence and disorder between the races. Any ordinary person could only conclude from the libelous character of the language that a clash and riots would eventually result." No merit was found in the accused's claim that the statute is too broad in scope or that the words of the statute are too vague. ${ }^{\mathbf{1 0}}$ The accused attempted to prove the truth of the alleged libel by showing that offenses in Negro districts of Chicago were greater in number than in White, that his brother was shot by a Negro, and that Negro inhabitation was injurious to real estate values. The Supreme Court rejected such a defense on the grounds that it was "directed only to a portion of the offense charged and [the matter] could not in any manner be classed as published for good motives and justifiable ends."11

The Court rather summarily disposed of the constitutional aspects of defendant's contentions, relying on Bevins v. Prindable, ${ }^{12}$ which it cited as having upheld this same statute. It is noteworthy that the Bevins case merely held that an injunction should not issue against the operation of the statute, and the District Court expressly stated that "we do not find it now necessary to consider the constitutionality of the statute."13 It then concluded that the final burden of passing upon such question shifted to the state court:

"Whether a statute of the State of Illinois is valid which makes defamation of a class a criminal offense would seem first to be a question for the courts of Illinois."14

268 U.S. 652 (1925) and Chaplinsky v. New Hampshire, 315 U.S. 568 (1942).

8 First advanced by Holmes, J., in Schenck v. United States, 249 U. S. 47 (1919).

To the effect that the danger must be immediate, see Herndon $v$.

Lowry, 301 U.S. 242 (1937); see note 74, infra.

10 See note 81 infra.

11 People ₹. Beauharnais, supra note 3 , at 346 .

1239 F. Supp. 708 (E.D. Ill. 1941), affirmed by memorandum opinion

in 314 U.S. 573 (1941).

1s Bevins v. Prindable, supra note 12 , at 712 .

14 Ibia. 


\section{General Background of Criminal Group Libel- with Civil Analogies}

Before a detailed consideration of the criminal group libel statute as such is undertaken, a brief glance should be taken at some already formulated concepts of criminal group libel, and at civil group libel analogies.

The gravamen of the offense of criminal libel is generally regarded to be the tendency of the libelous words to provoke breaches of the peace. ${ }^{15}$ The fundamental theory behind the civil action for libel, on the other hand, seems to be the protection of the defamed individual's property interest in his reputation, ${ }^{16}$ and a reference of the libelous words to an ascertained or ascertainable person is a prerequisite to bringing the action. ${ }^{17}$ Hence the distinction: a criminal action is theoretically feasible against one defaming a group, ${ }^{18}$ whereas, in the case of the civil action, an individual group member is confronted with the task of

\footnotetext{
15 Neweld, SLander aNd LIBEe, § 807 (4th Ed. 1924); Note, 19 A.L.R. 1470, at 1473. See Chafee, Freedons of Speech iN the United States, p. 15 (1941).

${ }^{16}$ Prosser, ToRTs, 777 (1941); Pound, Interests of Personality, 28 HARv. L. REv. 343 (1915). For an excellent discussion of group libel statutes generally, see Note, Statutory Prohibition of Group Defamation, 47 CoL. L. REv. 595 (1947). For a most illuminating study of group libel, see Reisman, Democracy and Defamation: Control of Group Libel, 42 CoL. L. REv. 727 (1942). It would seem indeed infrequent that a libelee would pass up an opportunity to get money damages in a civil action, but the same incentive does not obtain in the criminal prosecution.

${ }^{17}$ See Wilner, The Oivil Liability Aspect of Defamation Directed Against a Collectivity, 90 U. of PA. L. Rev. 414 (1942).

${ }_{18}$ See People v. Eastman, 188 N.Y. 478, 81 N.E. 459 (1907), wherein, after reversing a conviction under an obscenity statute for making a scurrilous attack upon a large group of Catholic clergymen, the Court pointed out that a criminal prosecution could be maintained upon the theory of inciting a breach of the peace, and that "therefore, a criminal prosecution can be sustained where no civil action will lie, as for instance, in this very case, where the libel is against a class." But an indictment for libeling all persons of the Jewish faith was dismissed in People v. Edmundson, 168 N.Y. Misc. 142, 4 N.Y. Supp. 2d 257 (1938); accord, Regina v. Gathercole [1838] 2 Lewin 237, 168 Eng. Rep. 1140, wherein it was stated that a "person may, without being liable to prosecution for it, attack Judaism, ... or even any sect of the Christian religion," but that prosecution would lie for libel against an identified group.
} 
identifying himself as the one toward whom the defamatory words are directed. This departure in theory, however, does not render worthless a resort to civil analogies, especially in determining the identity of group, the size thereof, and, in some cases, the libelous nature of the words used, all of which are factors often determinative of the probability of a breach of the peace.

A staunch reluctance on the part of the courts to entertain civil suits for group libel, ${ }^{19}$ and a widespread disinclination on the part of state officials to prosecute criminal libel actions based upon a probable breach of the peace, ${ }^{20}$ can perhaps best explain not only the existence of the instant statute upon the Illinois books, but also pleas for legislation by those minority groups most vulnerable to libelous attack for reasons of race, religion, or political inclinations.

An American tradition of individualism and "an oversensitivity to the commercial aspects of reputation" have been suggested as philosophical bases for the judicial reluctance to entertain civil group libel suits. ${ }^{21}$ However, the practical impediments are broad concepts of free speech and of the press, ${ }^{22}$ narrow fears of multiplicity of suits, ${ }^{23}$ and belief that existing criminal sanctions are sufficient without civil intervention. ${ }^{24}$

Illustrative of perhaps the maximum extent to which courts will go in civil group libel actions is the Canadian case of Ortenberg $v$. Plamodon, ${ }^{25}$ where the Court permitted recovery by a member of the defamed class, all of the Jews in the city of Quebec, who numbered only seventy-five, a

\footnotetext{
10 Statutory Prohibition of Group Defamation, supra note 16, 598 et seq.; Reisman, op. cit. supra note 16, 730 et seq.

so Statutory Prohibition of Group Defamation, supra note 16, 600 et seq.

21 See notes 16 and 19 supra.

2 Ryckman v. Delavan, 25 Wend. (N.Y.) 186, 199 (1840) ; People v. Edmundson, supra note 18, 154; Prosser, TokTs, Sec. 94 (1941). See also note 19 supra.

$\approx$ See Sumner v. Buel, 12 Johns (N.Y.) 475, 478 (1815). See note 17 supra. See also Note, 21 TEx. L. REv. 819 (1943).

is Statutory Prohibition of Group Defamation, supra note 16, 599; see note 23 supra.

25 35 Can. L. Thares 262, ANn. Cas. $1915 \mathrm{C} 347$ (1914).
} 
number small and ascertainable enough to impute direct designation of the individual member. A more recent Kentucky decision ${ }^{26}$ has repudiated the above case. Finding that the Canadian holding is not binding in the United States because based upon French instead of English precedent, the Court held that a defamed member of a family clan had no cause of action because the clan was too large and the communication too indefinite to impute injury to an individual member. Although recoveries have been permitted in some instances where the defamed plaintiff was one of seventeen accused of murder, ${ }^{27}$ a family, ${ }^{28}$ a twelveman jury, ${ }^{29}$ twelve doctors discharged by a hospital, ${ }^{80}$ a board of medical examiners, ${ }^{31}$ six brewing and malting firms, ${ }^{32}$ four physicians in a coroner's office, ${ }^{83}$ and the subordinate engineers of a corporation, ${ }^{84}$ court disfavor of civil actions of libel against a group is illustrated by denial of recovery to a member of one of the following groups: proprietors of correspondence schools, 35 "wine joint" owners in a certain city, ${ }^{36}$ French-Canadians, ${ }^{37}$ insurance agents, ${ }^{38}$ those engaged in a particular business in a city, ${ }^{30}$ an army

${ }^{28}$ Louisville Times v. Stivers, $252 \mathrm{Ky.} \mathrm{843,} 68$ S.W. 2d 411, 97 A.L.R. 277 (1934).

${ }^{27}$ Foxcroft v. Lacy, 80 Eng. Rep. 239 (1613), where libelees were accused of murder subsequent to acquittal in a conspiracy trial.

${ }_{23}$ Fenstermaker $\nabla$. Tribune Pub. Co., 13 Utah 532, 45 Pac. 1097 (1896).

29 Byers v. Martin, 2 Colo. 605, 25 Am. Rep. 755 (1875), where the jury's verdict was called "infamous"; Smallwood จ. York, 163 KJ. 139, 173 S.W. 380 (1915). See also Welch v. Tribune Pub. Co., 83 Mich. 661, 47 N.W. $562(1890)$.

so Bornmann V. Star Co., 174 N.Y. 212, 66 N.玉. 723 (1903), where the doctors were called jackasses in the guise of doctors.

sI Fullerton V. Thompson, 123 Minn. 136, 143 N.W. 260 (1913).

32 Ryckman $\nabla$. Delavan, supra note 22 , where the firms were repre. sented as engaging in filthy production practices.

33 Weston v. Commercial Advertiser Ass'n, 184 N.Y. 479, 77 N.æ. 660 (1906), where physicians were accused of graft and extortion of money.

3s Hardy $\checkmark$. Williamson, 36 Ga. 551, 12 S.E. 874 (1891), where only "some of them" were referred to.

ss International Text-book Co. v. Leader Printing Co., 189 Fed. 86 (C.C. Ohio 1910).

${ }^{20}$ Comes . Cruce, 85 Ark. 79, 107 S.W. 185 (1908).

${ }^{27}$ Germain v. Ryan, 53 Rap. Jud. 543 (C.S. Quebec 1918).

28 McGee v. Collins, 156 La. 291, 100 So. 430, 34 A.L.R. 336 (1924).

watson v. Detroit Journal Co., 143 Mich. 430, 107 N.W. 81 (1906). 
accused of cowardice, ${ }^{40}$ a family clan engaged in fist fights and gun battles, ${ }^{41}$ "officers" of a workers' alliance, ${ }^{42}$ a group of twenty-three lawyers called "scum and shysters",43 and more recently, drivers of a taxicab company. ${ }^{44}$

Notwithstanding the lack of necessity for showing damage $^{45}$ or identity of the individual in the group, there have been few criminal prosecutions in the United States for group libel. ${ }^{46}$ Aside from constitutional curbs, ${ }^{47}$ policy considerations play a prominent role in discouraging prosecutions. Whenever the defamed party has an adequate civil remedy, seldom are criminal proceedings instituted. ${ }^{48}$ The principal reason attributed to such inaction is the practical difficulty of obtaining convictions through unanimous verdicts by juries predominantly partial toward the criminal defendant, especially in the case of minor offenses. ${ }^{49}$ Proof beyond a reasonable doubt is almost too much to be hoped for in the instance of an "offense which defies exact definite-

¿ Palmer v. City of Concord, 48 N.H. 211, 97 Am. Dec. 605 (1868).
\& Louisville Times v. Stivers, supra note 26.
Noral v. Hearst Publications, Inc., 40 Cal. App. 2d 348, 104 Pac. 2d 860 (1940), where the plaintiff was one of only three paid officials, but the court held that the term "officers" was not confined to those receiving compensation.

" Latimer v. Chicago Dally News, Inc., 330 Ill. App. 295, 71 N.E. 2d 553 (1947), where the court stated that it must be said with certainty that every individual member in the class must be included in the com. munication, and that no innuendo can render certain identity of persons libeled. But $c f$, note 34 supra. See also Gross v. Cantor, 270 N.Y. 93, 200 N.E. 592 (1936), where all radio editors were referred to, save one.

" Fowler v. Curtis Publishing Co., 182 Fed. 2d 377 (D.C. Cir. 1950). See Note thereon in 24 So. CAL. L. REv. 213 (1951).

is Tracy v. Commonwealth, $87 \mathrm{Ky} .584,586,9$ S.W. 822, 824 (1888). See Wilner, op. cit. supra note 17, 437, and Statutory Prohibition of Group Defamation, supra note 16,600 .

40 People v. Turner, 28 Cal. App. 766, 154 Pac. 34 (1915); Crane v. State, 14 Okla. Crim. Rep. 30, 166 Pac. 1110 (1917). See note 18 supra. Regarding the rarity of such prosecutions, see Reisman, op. cit. supra note 16, 747 et seg.

4 See discussion infra p. 225 et seq.

(8) Reisman, op. cit. supra note 16, at 748. Query whether there be any basis for such an excuse, especially if the civil courts simultaneously consider criminal sanctions adequate. See note 24 supra.

o Reisman, op. cit. supra note 16, at 748 . 
ness." Then, too, the conviction of a person crying "Free speech!" conceivably would label him a martyr in the eyes of many; while acquittal might be publicly misunderstood as judicial endorsement of his defamatory appellations." 5 Hence, criminal libel statutes protecting individuals have been termed "so clumsy as a weapon and so inefficient as a deterrent" that their abolition has been recommended.52

For similar reasons, legislative attempts to afford minority groups protection from libelous onslaughts by the imposition of criminal penalties for group libel have generally failed.53 It would seem to follow that if such protection is to be afforded, it must be either through the legislative imposition of more stringent criminal sanctions overriding current judicial apathy toward such actions, or through an extension of the scope of the civil action to include individual members of larger groups. 712.

${ }^{50}$ Ibia. Quoted portion from Bevins v. Prindabie, supra note 12 at

5. Reisman, op. cit. supra note 16, at 755. See note 20 supra.

E2 EARNST \& LINDLEY, HOLD YOUR TONGUE!, 329 (1932); Wilner, op. cit supra note 17, at 438; Reisman, op. cit. supra note 16, at 750, 754 .

w The instant Illinois statute, supra note 2 , so far as cases found reveal, has been successfully involed to obtain a conviction only iu the instant case of People v. Beauharnais, supra note 3. Bevins v. Prindable, supra note 12, involved the question of whether or not the operation of the statute should be enjoined; People v. Speilman, 318 Ill. 482, 149 N.E. 466 (1925) upheld a conviction for group libel against members of the American Legion, but under the ordinary llbel statute, currently found in Irr. REv. Stat., Chap. 38, Par. 402 (1949). See also People V. Simcox, 379 III. 347, 40 NE.2d 525 (1942), where complaint dismissed.

See Mass. ANr. Laws, tit. 9, Chap. 272, Sec. 98c (Michle Supp. 1946), commented on in 28 MASS. L. Q., no. 4, 104 (1943), which comment quoted from Boston Herald, May 28, 1943: "The Act will not quiet the tongues of the venomous and it is so drawn that probably few actions will be brought, but there it is on the books, it can be invoked." No case has been found which does invoke this statute.

A New Jersey group libel statute, N.J. REv. STAT., tit. 2, Sec. 157B (1937), was held unconstitutional in State v. Klapprott, 127 N.J.L. 395, 22 Atl. 2d 877 (1941) as violative of free speech guaranty and as being void for vagueness. The statute made no distinction betweeu private and public speech; see discussion infra, p. 229 et seq.

For a suggested civil and criminal group defamation statute, see Statutory Prohibition of Group Defamation, supra note 16, 608 et seg. 


\section{Constitutional Limitations Upon State Control of Group Libel}

In view of the United States Supreme Court's adherence to the doctrine that the Fourteenth Amendment prohibitions do not apply to actions of individuals, ${ }^{54}$ and in view of Congress's inactivity in the field of group libel, ${ }^{55}$ offended minorities must depend upon the states for aid. Since the decision of Gitlow $v$. New York $k^{56}$ in 1925, the guaranties of the First Amendment have been regarded as a part of the Fourteenth, and, hence, as a limitation upon state activity. The Illinois statute, ${ }^{\overline{5} 7}$ or any statute under which criminal sanction is given for group libel, must therefore accord with the United States Supreme Court's concepts of the guaranties of the First Amendment.

As suggested by the Illinois Supreme Court in the principal case of People $v$. Beauharnais, ${ }^{58}$ which cites with approval Gitlow v. New York ${ }^{59}$ and Chaplinsky v. New Hampshire, ${ }^{\circ 0}$ rights of speech and of the press are not absolute, and for abuse of these rights punishment may lie. Protected speech has been said to embrace "at least the liberty to discuss publicly and truthfully all matters of public concern without previous restraint or fear of subsequent punishment,"61 but speech becomes a subject of at least limited state interference when it is associated with violence, ${ }^{62}$ when it becomes an instrument of coercion rather than persua-

of Civil Rights Case, 109 U.S. 3 (1883); United States v. Cruikshank, 92 U.S. 542 (1875).

* See discussion in Statutory Prohibition of Group Defamation, supra note 16 , at 602 .

co 268 U.S. 652 (1925).

is See note 2 supra.

$\leftrightarrow$ See note 3 supra.

59 See note 56 supra.

co 315 U.S. 568 (1942).

a Thornhill v. Alabama, 310 U.S. 88, 101 (1940), which held that no state may impose a blanket restriction upon picketing. Regarding previous restraint see Near v. Minnesota, 283 U.S. 697 (1931); Cantwell v. Connecticut, 310 U.S. 296 (1940); Schneider v. New Jersey, 308 U.S. 147 (1939).

62 Milk Wagon Drivers Union v. Meadowmoor Dairies, 312 U.S. 287 (1941). 
sion, ${ }^{63}$ when of such commercial nature that regulation is essential, ${ }^{* \pm}$ when lewd, obscene, profane, or "fighting" words are used," ${ }^{6 \bar{z}}$ or when words are used in "such circumstances and are of such a nature as to create a clear and present danger that they will bring about the substantive evils" that the state has a right to prevent. ${ }^{66}$

There is no convenient, precisely defined line of demarcation between legitimate speech, such as is in the public interest, on the one hand, and speech which, by either its misuse or the context in which it is used, becomes a proper object for state policing. The United States Supreme Court has purposely avoided the imposition of rigid and unyielding prescriptions for state resolution of the internal conflict between freedom and order; ${ }^{67}$ rather, the Court seems to prefer that this conflict be dealt with by the state courts' own sincere interpretation of Supreme Court "guides."68 The imaginary line might be said to fall somewhere between an honest attempt on the part of the speaker or writer to change men's minds and a deliberate use of abusive language to stir up trouble. ${ }^{69}$ This distinction was made in the case of Cantwell $v$. Connecticut, ${ }^{70}$ wherein a conviction for a breach of the peace was reversed because the playing by Jehovah's Witnesses of phonograph records attacking the Catholic Church was not regarded as a substantive evil which the State could prevent, since there was not a "clear and present danger" that violence would result, and since this is merely a sincere, persuasive method of "proselyting."

The Supreme Court has indicated that the "clear and present danger" must be immediate, ${ }^{71}$ and certiorari was

\& NLRB v. Virginia Elec. \& Power Co., 314 U.S. 469 (1941).

os Valentine v. Christensen, 316 U.S. 52 (1942).

๘ Chaplinsky $\nabla$. New Hampshire, supra note 60, 571; Cantwell จ. Connecticut, supra note 61,482 .

${ }^{68}$ Schenck v. United States, supra note 8.

or Thomas v. Collins, 323 U.S. 516, 529 (1945); Niemotko v. Maryland, 340 U.S. 268 (1951).

${ }^{\infty}$ See note 83 infra, and quoted "guides" infra pp. 228, 229.

${ }^{\infty}$ See Note, 24 Ird. L. J. 78, 86 (1949).

70 See note 61 supra.

71 Herndon v. Lowry, supra note 9. 
recently denied in the case of Sellers $v$. Johnson, ${ }^{72}$ wherein a sheriff was enjoined from preventing a lawful meeting of Jehovah's Witnesses on the mere pretext that a riot would inevitably result. But a state disorderly conduct conviction of a street speaker, who made attacks upon various officials and sought to arouse Negroes to armed enforcement of their rights, was upheld in Feiner $v$. New York. ${ }^{73}$ Here, however, the arrest was made after the speaker had been asked by policemen to stop, and after it became apparent to the policemen that violence and a breach of the peace would result. Vinson, C. J., delivering the opinion of the Court stated the distinction:
"It is one thing to say that the police cannot be used as an instrument for the suppression of un- popular views, and another to say that, when as here the speaker passes the bounds of argument or persuasion and undertakes incitement to riot, they are powerless to prevent a breach of the peace."74

In the case of Chaplinsky $v$. New Hampshire, ${ }^{75}$ a conviction of a street speaker who used "fighting words" in violation of a state statute was upheld. It is noteworthy here that the State courts had previously held the statute applicable to words used in a public place directly tending to provoke a breach of the peace. A breach of the peace, however, may not be defined in such broad terms as speech which merely "stirs the public to anger, invites disputes, brings

\footnotetext{
T2 163 Fed. $2 d 877$ (8th Cir. 1947), cert. denied, 322 U.S. 851 (1948).

3340 U.S. 315 (1951).

"Feiner v. New York, supra note 73. Mr. Justice Black, dissenting, considers the decision "a long step toward totalitarian authority"; that it amounts to approval of "a simple and readily available technique by which cities and states can with impunity subject all speeches, political or otherwise, on streets or elsewhere, to the supervision and censorship of the local police."

To See note 60 supra.
} 
about a condition of unrest, or creates a disturbance," especially in the case of a private hall. ${ }^{76}$

In a special opinion concurring with the majority, Justice Frankfurter combines for consideration the recent cases of Niemotko v. Maryland, ${ }^{77}$ Kunz v. New York, ${ }^{78}$ and Feiner v. New York ${ }^{79}$ where he attempts in summary fashion to give some guides for reconciling the conflict between speech and other interests, such as public order. He poses pertinent questions on which decisions turn and briefly gives answers:

"(1) What is the interest deemed to require the regulation of speech? The State cannot of course forbid public proselyting or religious argument merely because public officials disapprove the speaker's views. It must act in patent good faith to maintain the public peace, to assure the availability of the streets for their primary purposes of passenger and vehicular traffic, or for equally indispensable ends of modern community life.

"(2) What is the method used to achieve such ends as a consequence of which public speech is constrained or barred? A licensing standard which gives an official authority to censor the content of a speech differs toto coelo from one limited by its terms, or by nondiscriminatory practice, to considerations of public safety and the like. Again, a sanction applied after the event assures consideration of the particular circumstances of a situation. The net of control must not be cast too broadly.

"(3) What mode of speech is regulated? A sound truck may be found to affect the public peace as normal speech does not. A man who is calling names or using the kind of language which would reasonably stir an-

7o Terminiello v. City of Chicago, supra note 5, wherein the Supreme Court reversed a conviction under a city disorderly conduct ordinance. While addressing an anti-Semitic meeting in a private hall, defendant referred to $a \mathrm{mob}$, which was picketing the hall and which had made some assaults upon attenders of the meeting, as "slimy scum." The con. viction was upset largely upon the broad grounds upon which the trial court defined a breach of the peace.

$\pi$ See note 67 supra.

78 340 U.S. 290 (1951).

7 See note 73 supra. 
other to violence does not have the same claim to protection as one whose speech is an appeal to reason.

"(4) Where does the speaking which is regulated take place? Not only the general classificationsstreets, parks, private buildings-are relevant. The location and size of a park; its customary use for the recreational, esthetic and contemplative needs of a community; the facilities, other than a park or street corner, readily available in a community for airing views, are all pertinent considerations in assessing the limitations the Fourteenth Amendment puts on State power in a particular situation." 80

Any state statute which limits the exercise of speech, and imposes criminal penalties upon abuses thereof, must not be so vague in its terms or so indefinite in setting forth the type of conduct made subject to penalty as to violate well settled notions of due process of law. If the statute is so broad and vague as to permit within the scope of its language the punishment of incidents fairly within the protection of free speech, it is void-especially if men of common intelligence must necessarily guess at its meaning, and differ as to its application. ${ }^{81}$ In State $v$. Klapprott ${ }^{82}$ the New Jersey Supreme Court held a New Jersey group libel statute unconstitutional from the standpoint of vagueness. Such terms as "hatred," "abuse," and "hostility" were regarded as abstract terms, and the court concluded:

"The criminal code must be definite and informative so that there may be no doubt in the mind of the citizenry that the interdicted act or conduct is illicit."83

In considering challenges to the constitutionality of state statutes, the United States Supreme Court encourages, and

so Niemotko v. Maryland, supra note 67, at 282, 283.

si Winters v. New York, 333 U.S. 507, 509 (1948); Cantwell v. Connecticut, supra note 61, at 308; Lanzetta v. New Jersey, 306 U.S. 451, 453 (1939) ; Carlson v. California, 310 U.S. 106, 112 (1940); Herndon v. Lowry, supra note 9, at 258. But cf. Communications Ass'n v. Douds, 339 U.S. 382, 413 (1950). "A mind intent upon willful evasion is inconsistent with surprised innocence." United States v. Ragen, 314 U.S. 513, 524 (1942).

See note 53 supra.

State V. Klapprott, supra note 53. 
gives considerable weight to, firm declarations of state policy, and the Court occasionally will allow the state courts to rectify an otherwise too vague statute by a narrow interpretation thereof. ${ }^{84}$ Generally speaking, however, statutes limiting free speech are strictly construed upon the face of the statute.

\section{Possible Defects in the Mlinois Criminal Group Libel Statute}

The Illinois statute which imposes criminal penalties for libeling a group reads as follows:
"It shall be unlawful for any person, firm or corpora- tion to manufacture, sell, or offer for sale, advertise or publish, present or exhibit in any public place in this state any lithograph, moving picture, play, drama or sketch, which publication or exhibition portrays de- pravity, criminality, unchastity, or lack of virtue of a class of citizens, of any race, color, creed or religion, which said publication or exhibition exposes the citi- zens of any race, color, creed or religion to contempt, derision, or obloquy or which is productive of breach of the peace or riots. Any person, firm, or corporation violating any of the provisions of this section, shall be guilty of a misdemeanor, and upon conviction thereof, shall be punished by a fine of not less than fifty ... nor more than two hundred dollars ...."85

Whether or not there may be inherent in this statute defects upon which its constitutionality might properly be challenged can best be revealed by a brief analysis of its provisions. The questions which Mr. Justice Frankfurter suggested as general guides may be helpful in this analysis. ${ }^{86}$ The interest deemed to require the regulation of speech is that of protecting minority groups from abusive libels, which, it is submitted, is an interest calling for state aid through criminal sanctions. The frequent use of the disjunctive, however, lends uncertainty as to the scope of the

\footnotetext{
8s Chaplinsky v. New Hampshire, supra note 60, at 574; Fox v. Washington, 236 U.S. 273, 276 (1915); but of. Herndon v. Lowry, supra note 9. $\approx$ See note 2 supra.

${ }^{s 0}$ See pp. 228, 229 supra, and note 80 supra.
} 
interest sought to be protected. Is non-exposure of a class of "citizens of any race, color, creed or religion to contempt" so much in the public interest that one may not with impunity write that "all Jews are contemptible," or even that some of them are? Must the public peace be actually threatened? How far may one go in religious proselyting?

The statute imposes a sanction after the event, hence avoiding prior censorship or restraint of the nature condemned by the Court. But is the "net of control" not cast so broadly as to include therein language fairly within the protection of free speech and of free press? Would not men of ordinary intelligence conjecture as to the meaning of the terms of the statute, or differ as to its application?

Insofar as the subject matter of the speech sought to be regulated is confined to that which would reasonably stir others to violence, the statute is perhaps within constitutional limits. But there would appear great room for interpretation of the terms of the statute to include, and infringe upon, the legitimate exercise of speech, such as may be considered in the public interest, or that which in fact would never be calculated to incite libelees to rioting and violence. It is easily conceivable that many publications purportedly within the contemplation of the terms of the statute could be publicly displayed and yet would not be of such a nature as to create a clear and present danger of the evils which the state has a right to prevent. A great saving feature of the statute, however, is that it provides that the publication must be exhibited in a public place.

The uncertainties above suggested may or may not be such defects as would, under a current United States Supreme Court test of validity, render the statute unconstitutional, but it is submitted that the threat of such an invalidating decision could be appreciably reduced by a few minor changes in the statute: deletion of all of the first sentence appearing after the words "class of citizens, of any race, color, creed or religion, which said publication or exhibition," and, after the above quoted words, substitution of the following: "because of the defamatory nature thereof, either actually provokes and produces a breach of the peace, 
or provokes and produces such a clear and imminent threat of a breach of the peace as it would be the duty of a police officer to prevent."

Although the above suggested alteration would perhaps safely ward off challenges to constitutionality, it would somewhat reduce the apparent scope of the instant statute. But it can at least be said that such an alteration would lessen the need for would-be defamers to speculate as to the meaning of the terms, or as to the nature of the offense.

Inasmuch as it is the prevention, without prior restraint, of libelous onslaughts against minority groups that is the statutory end desired to be achieved, and surely a big factor in the maintenance of public peace, it would seem that an appreciable enhancement in the penalty provisions of the statute would serve to discourage the dissemination of at least the truly notorious libels, those most certain to provoke breaches of the peace. The greater weight of the penalty should induce a greater weighing of words. The enhancement in penalty might take the form of a revocation, or at least a temporary suspension, of the corporate charter of the printing, publishing, or exhibiting corporation-an afterthe-event sanction, although it might be considered a prior restraint on future publication. ${ }^{87}$ The suspension might valialy be imposed pending the payment of a heavy fine, or be invoked after a second conviction under the statute. Were suspension or revocation of corporate charters at stake, or a penalty of comparable propensity, printers would more scrupulously seek to avoid public portrayal of minority groups as depraved, criminal, unchaste, or lacking in virtue, and battles of propaganda would doubtless be fought upon a more elevated plane of moral decency and respectability.

\section{Conclusion}

That the protection of classes of persons from libelous onslaughts which provoke peace disturbances is a socially desirable field for state policing is by no means to be ques-

${ }^{52}$ See People $\nabla$. White Circle League of America, _. III. _, 97 N.E. 2d 811 (1951), wherein revocation of corporate charter was upheld. 
tioned. Whether of a civil or of a criminal nature, legislation directed toward affording adequate protection to minority groups has been on the whole none too successful. While there are practical and administrative obstacles standing in the way of success, perhaps the greatest barrier is the United States Constitution, which, as interpreted by the Courts, most jealously guards individual guaranties, sometimes at the expense of group interests. All too frequently, perhaps, the particular individual whose speaking rights are so religiously protected is a mere judgment-proof propaganda medium through whom large subversive organizations under protective shields publish and disseminate highly injurious, libelous matter to the unwarranted detriment of defenseless minority groups-defenseless, save to the small extent that state legislatures and courts have in fact recognized the problem and given it some criminal sanction.

It has become well settled that the guaranties of the First and Fourteenth Amendments are not absolute, and where abuse of these guaranties becomes of such nature that the public peace is either threatened or disturbed, it becomes a proper subject of state regulation. But any statute in derogation of these guaranties must accord with the formulated concepts regarding exceptions to the right to speak or write with impunity, and must not be couched in such vague terms that the nature and limit of the offense is necessarily a subject of speculation. 